\title{
Erythema elevatum diutinum
}

INSERM

\section{Source}

INSERM. (1999). Orphanet: an online rare disease and orphan drug data base. Erythema elevatum diutinum. ORPHA:90000

Erythema elevatum diutinum (EED) is a distinctive form of chronic cutaneous vasculitis, belonging to the group of the neutrophilic dermatoses. 